Науковий вісник НлТУ України Scientific Bulletin of UNFU

https://nv.nltu.edu.ua

https://doi.org/10.36930/40290811

Article received $20.09 .2019 \mathrm{p}$.

Article accepted 31.10.2019 p.

удк 502.[171+51](285)
ISSN 1994-7836 (print)

ISSN 2519-2477 (online)

$@ \bowtie$ Correspondence author

U. B. Bashutska

bashutska@nltu.edu.ua

Національний лісотехнічний університет Украӥни, м. Львів, Украӥна

\title{
РЕКУЛЬТИВАЦІЯ ОЗЕРА МЕТОДОМ ПУЛЬВЕРИЗАЦІЙНОЇ АЕРАЦІЇ ВОДИ В УМОВАХ РОЗТАШУВАННЯ МЕТЕОРОЛОГІЧНОЇ СТАНЦІЇ РАВА-РУСЬКА
}

Розглянуто технологію рекультивації озера технічним методом в умовах розташування метеорологічної станції РаваРуська. Проаналізовано досвід і результати роботи польських науковців. Відзначено позитивні результати внаслідок застосування у рекультивації природних і штучних водойм пульверизаційних аераторів, які розпилюють воду в повітрі. Представлено розподіл пульверизаційних аераторів води, що використовуються під час рекультивації озер. Охарактеризовано пульверизаційний аератор із вітровим приводом концепції Подсядловського. Ця технологія передбачає використання енергії вітру для насичення киснем нижньої зони озера. Робота аератора забезпечує утворення на кумулятивній глибині життєвого простору, в якому інтенсивно розвиваються фіто- і зоопланктон, а також риби, які ним харчуються. Регулярне виловлювання швидко зростаючої риби дає змогу знизити трофність озера та систематично покращити якість води. Пульверизаційний аератор води із вітровим приводом в умовах розташування метеостанції Рава-Руська може забезпечити розчинення кисню в донних водах в межах від 4,86 до 5,53 $\Gamma^{\cdot} \mathrm{M}^{-3}$. Найнижчі концентрації розчиненого кисню у воді зафіксовано в липні та серпні $\left(4,86 \Gamma^{\cdot} \mathrm{M}^{-3}\right)$, а найвищі $\left(>5,24 \Gamma^{\cdot} \mathrm{M}^{-3}\right)-$ із жовтня по травень. Опрацьовано і описано номограму для визначення вмісту кисню, розчиненого у воді впродовж певного місяця, внаслідок функціонування пульверизаційний аератор із вітровим приводом в умовах розташування метеостанції Рава-Руська. Рекомендовано застосування пульверизаційного аератора із вітровим приводом для рекультивації озер України.

Ключові слова: рекультивація озера; пульверизаційний аератор води; вітрова енергія; розчинений кисень.

Вступ. Водні ресурси України є життєво важливим природним ресурсом, що має особливе значення. Вони представлені переважно місцевим і транзитним стоками річок, водними запасами озер, штучних водойм і підземних горизонтів. Україна належить до держав 3 недостатнім забезпеченням водними ресурсами (Водні ресурси України // http://www.nbuv.gov.ua/node/3972). У водоймах за антропогенного впливу розвиваються кілька процесів: змінюються основні фізико-хімічні властивості води, відзначаються процеси евтрофікації та закислення, є токсичне забруднення. Великі природні водойми тривалий час мають значне антропогенне навантаження, зумовлене діяльністю і розвитком гірничодобувних, металургійних, целюлозно-паперових підприємств, міст і селищ та ін. Внаслідок цього відбуваються незворотні процеси, які торкаються всіх ланок водних екосистем.

На сьогодні складно знайти водні об'єкти, не модифіковані внаслідок надмірних антропогенних навантажень та кліматичних змін. Проте збереження високої якості вод $\epsilon$ необхідною умовою збереження здоров'я населення, біорізноманіття, естетичного та рекреаційного потенціалу природи. Підвищити якість відкритих поверхневих вод можна за допомогою технічних, хімічних та біологічних меліоративних заходів. Наприклад, зменшення надходження фосфору, насичення киснем, насичення шару води азотовмісними сполуками, осадження фосфору у воді при застосуванні $\mathrm{Al}^{2+} / \mathrm{Fe}^{3+}$, фосфору у воді при застосуванні сполук заліза, підняття рівня води, вилучення донних осадів, біоманіпуляція (регулювання популяцій риб, висаджування підводних рослин) та ін. Їхнє головне завдання полягає у забезпеченні близьких до нормативних якісних показників води у найкоротші терміни.

У меліоративній аерації природних і штучних водойм дедалі більше використовують пульверизаційні аератори, які розпилюють воду в повітрі (Chańko et al., 2001; Konieczny, 2002; Osuch \& Podsiadłowski, 2012; Podsiadłowski et al., 2018; Aerator, 2019; Bashutska, 2019). Їх поділяють на гравітаційні (не потребують постачання енергії ззовні, використовуючи так званий "ефект водоспаду") і механічні (використовують електричну або вітрову енергію) (таблиця).

Аналіз робіт польських науковців (Chańko et al., 2001; Konieczny, 2002; Osuch \& Podsiadłowski, 2012; Podsiadłowski et al., 2018; Aerator, 2019) показав, що серед пульверизаційних аераторів води особливу увагу заслуговує аератор з вітровим приводом Подсядловського. При його використанні спостерігалася низька аварійність і енергоємність робочих елементів, висока гідравлічна ефективність, аерація і дегазація прибережних вод озер будь-якої глибини. Пульверизаційний аератор

Інформація про авторів:

Башуцька Уляна Богданівна, канд. с.-г. наук, доцент, кафедра екології. Email: ecology@nltu.edu.ua; https://orcid.org/0000-0002-4131-014X

Цитування за ДСту: Башуцька У. Б. Рекультивація озера методом пульверизаційної аерації води в умовах розташування метеорологічної станції Рава-Руська. Науковий вісник НлтУ України. 2019, т. 29, № 8. С. 70-73.

Citation APA: Bashutska, U. В. (2019). Lake reclamation by the method of pulverising aeration of water in the conditions of location of meteorological stations of Rava-Ruska. Scientific Bulletin of UNFU, 29(8), 70-73. https://doi.org/10.36930/40290811 
Подсядловського (рис. 1, 2) є двокомпонентним, частково зануреним у воду і відкритим зверху роздрібним сегментом (1) у вигляді насосної камери (2) і водозабірної камери (3) (Konieczny, 2013a).

Таблиця. Класифікація пульверизаційних аераторів води (Osuch, 2014)

\begin{tabular}{|c|c|c|}
\hline \multicolumn{3}{|c|}{ Пульверизаційні аератори } \\
\hline \multirow{2}{*}{$\begin{array}{c}\text { Гравітаційні } \\
\text { аератори }\end{array}$} & \multicolumn{2}{|c|}{ Механічні аератори } \\
\hline & $\begin{array}{c}3 \text { електричним } \\
\text { приводом }\end{array}$ & $\begin{array}{c}3 \text { вітровим } \\
\text { приводом }\end{array}$ \\
\hline
\end{tabular}

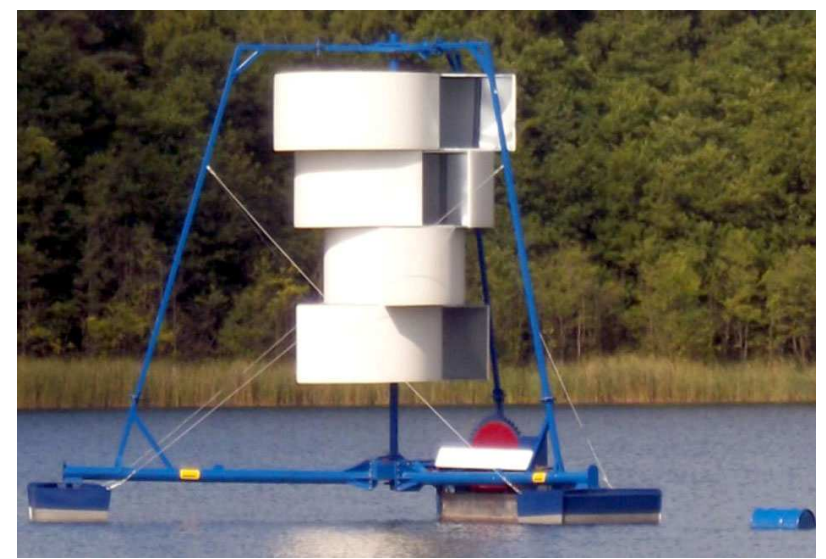

Рис. 1. Пульверизаційний аератор з вітровим приводом (Konieczny, 2013a)

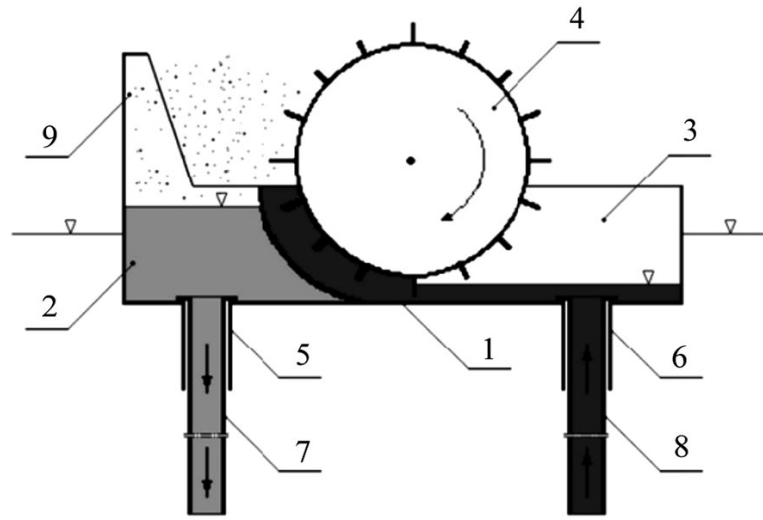

Рис. 2. Будова сегмента вітроенергетичного аератора концепції Подсядловського (Konieczny, 2013a): 1) розпилювальний сегмент; 2) насосна камера; 3) водозабірні камери; 4) лопатеві колеса; 5) сопло труби розпилювальної камери; 6) сопло труби водоприймальної камери; 7) шланг випуску води; 8) шланг забору води; 9) пластина розбризкування

Водозабірна камера (3) оснащена лопатевим колесом (4) із трьома шлангами для забору води (8), вбудованими в сопла (6), і насосною камерою (2) з розбризкуванням (9) і трьома випускними шлангами (7), розташованими в соплах (5). Робота лопатевого колеса відбувається від вітрової турбіни Савоніуса із вертикальною віссю обертання через систему із трьох передач (дві клинові пасові та кутова). Це спричиняє поглинання i дислокацію донної води через пульверизаційний сегмент аератора 3 одночасним розпиленням води в повітpi, дегазуванням i аерацією. У разі дефіциту кисню у придонних водах та швидкості вітру від 2,5 до 9,1 м · $\mathrm{c}^{-}$ 1 вміст розчиненого у воді кисню зростає від 0,7 до 4,8 кг·добу ${ }^{-1}$ (Konieczny, 2013a; Konieczny, 2013b).

Метою $є$ охарактеризувати роботу пульверизаційного аератора із вітровим приводом концепції Подсядловського та створити на основі даних про швидкість вітру метеорологічної станції Рава-Руська (Arkhiv pohody, 2007-2017) зразкову номограму для визначення вмісту розчиненого кисню у воді внаслідок роботи аератора. Отримані результати сприятимуть роботам із рекультивації поверхневих водойм України.

Методологія дослідження. Номограму концентрації кисню, розчиненого у воді внаслідок роботи пульверизаційного аератора води 3 вітровим приводом, було зібрано на основі даних інтернет-бази (Arkhiv pohody, 2007-2017) для метеостанції Рава-Руська щодо середньої тригодинної швидкості вітру (м с $\left.\mathrm{c}^{-1}\right)$ від 2007 до 2017 pp. Швидкості вітру в місяцях упорядковано із кроком $1 \mathrm{~m} \mathrm{c}^{-1}$. На основі статистичної моделі Конєчного (2002) у діапазоні швидкостей вітру від 2 до 9 м с1 визначено концентрацію розчиненого кисню у воді шлангів пульверизаційного аератора:

$$
\begin{gathered}
\hat{y}_{i}=-0,016524 \cdot x_{i}^{4}+0,398753 \cdot x_{i}^{3}-3,6109 \cdot x_{i}^{2}+ \\
+14,2775 \cdot x-14,1112,
\end{gathered}
$$

де: $\hat{y}_{i}$ - концентрація розчиненого кисню у воді шлангів пульверизаційного аератора, $\Gamma^{\cdot} \mathrm{M}^{-3} ; x_{i}-$ швидкість вітру, $v, \mathrm{M}^{-1} \mathrm{c}^{-1}$.

У розрахунках (1) на основі роботи Конєчного $(2013, b)$ передбачалися повна відсутність кисню у придонних водах, постійна ефективність насичення повітря киснем пульверизаційним аератором за швидкості вітру $v \geq 9,0 \mathrm{M} \cdot \mathrm{c}^{-1}$ та нульова ефективність за швидкості вітру $v<2 \mathrm{~m} \cdot \mathrm{c}^{-1}$. Отримані значення концентрації розчиненого кисню у воді було усереднено щомісячно у період 2007-2017 pр. на основі середньозваженої:

$$
x_{c p}=\sum_{i=1}^{n} z_{i} \cdot N_{i} / \sum_{i=1}^{n} N_{i}
$$

де: $x_{c p}$ - середнє зважене; $z_{1}, z_{2}, z_{n}$ - максимальні значення ряду розподілу; $N_{1}, N_{2}, N_{n}$ - кількість спостережень (число) у ряді розподілу.

Середньозважені значення концентрації кисню, розчиненого у воді, для аналізу було складено у вигляді графіка (номограми) залежної змінної, описаної поліноміальним 6-ступінчастим рівнянням регресії, в якому число місяця $є$ незалежною змінною. Рівняння регресії розроблено з використанням комп'ютерної програми Microsoft Excel. 3 огляду на практичний аспект отриманої номограми аналіз їі даних, опис рівняння регресії та графіка звужено до величини коефіцієнта детермінації (R2), а ступінь і коректність полінома - на основі стандартного відхилення випадкової складової $(\mathrm{Se})$ і коефіцієнта вираження $\left(V_{S e}\right)$.

Результати дослідження. Зміни значень концентрацій кисню, розчиненого у воді шлангів пульверизаційного аератора із вітровим приводом конструкції Подсядловського, подано у вигляді, описаному рівнянням регресії шостого ступеня залежності (номограма) від функції місяця (рис. 3). Ця залежність виправдана для умов розташування метеостанції Рава-Руська.

Правильність рівняння поліноміальної регресії для оцінки змін концентрації розчиненого кисню у воді внаслідок роботи пульверизаційного аератора води, як функції місяця, оцінювали на основі стандартного відхилення випадкової складової (Se), коефіцієнта вираження $\left(V_{S e}\right)$ та коефіцієнта детермінації $\left(R^{2}\right)$. Низькі значення стандартного відхилення випадкової складової $\left(S e=0,000106 \Gamma^{\cdot} \mathrm{M}^{-3}\right), \quad$ коефіцієнта вираження $\left(V_{S e}=\right.$ $0,002039 \%)$ та відносно високий коефіцієнт детермінації $\left(R^{2}=0,9149\right)$ доводять правильність, визначену з середньозваженого (2) залежностей (див. рис. 3). На осно- 
ві рівняння поліноміальної регресії можна знайти розбіжність значень концентрації кисню, розчиненого у воді, від 4,86 до 5,53 $\Gamma^{\cdot} \mathrm{M}^{-3}$.

Найнижчі концентрації кисню, розчиненого у воді, зафіксовано в липні та серпні $\left(4,86 \Gamma^{\cdot} \mathrm{M}^{-3}\right)$, а найвищі $\left(>5,24 \Gamma^{\cdot} \mathrm{M}^{-3}\right)-3$ жовтня по травень. Такий стан $є$ наслідком порівняно низьких швидкостей вітру влітку (в середньому 3,0 м· $\mathrm{c}^{-1}$ ) відносно швидкостей вітру, характерних для інших місяців року (в середньому від 3,2 до 3,9 $\mathrm{M}^{-1}$ ) (Arkhiv pohody, 2007-2017). 3 огляду на практичний аспект номограми, значення коефіцієнта детермінації при прогнозуванні змін концентрації розчиненого кисню у воді внаслідок роботи пульверизаційного аератора із вітровим приводом, вимагає обережності при інтерпретації даних, отриманих з рівняння поліноміальної регресії. Високе значення коефіцієнта детермінації (понад 90 \%) вказує на можливість використання рівняння регресії та графіка для імітації ефектів штучного насичення киснем води пульверизаційним аератором в місці розташування метеостанції Рава-Руська.

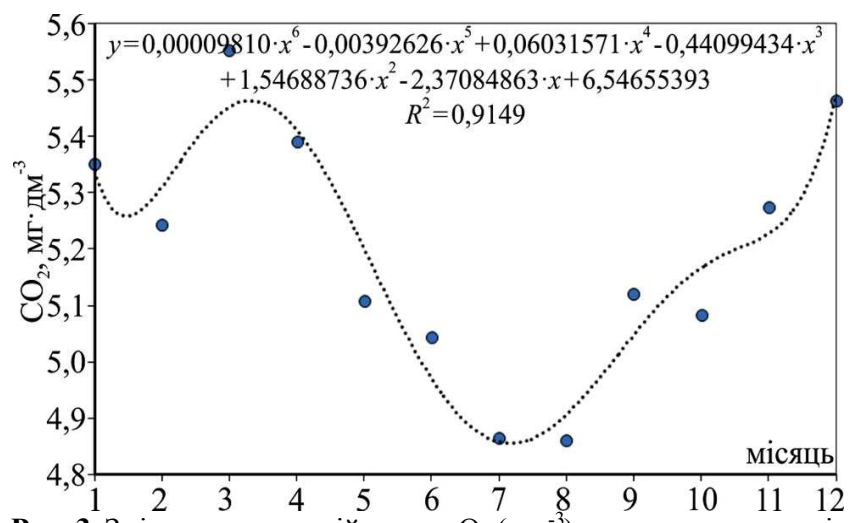

Рис. 3. Зміни концентрацій кисню $\mathrm{O}_{2}\left(\Gamma \cdot \mathrm{M}^{-3}\right)$, розчиненого у воді шлангів пульверизаційного аератора з вітровим приводом, у функції місяця в умовах розташування метеостанції Рава-Руська

Висновки та рекомендації. Основним способом покращення якості озер є уникнення потрапляння біогенних сполук речовин в озера. У багатьох випадках рівень деградації озерної екосистеми є настільки високим, що лише обмеження водопостачання біогенних сполук $є$ недостатнім для досягнення бажаного ефекту. Виникає потреба здійснювати відновлення озера. Аналіз праць польських науковців показав переваги рекультивації озер із використанням пульверизаційних аераторів води концепції Подсядловського. На підставі здійснених розрахунків сформульовано висновки. Пульверизаційний аератор води із вітровим приводом в умовах розташування метеостанції Рава-Руська може забезпечити розчинення кисню в донних водах у межах від 4,86 до 5,53 $\Gamma^{\cdot} \mathrm{M}^{-3}$. Найнижчі концентрації розчиненого кисню у воді зафіксовано в липні та серпні $\left(4,86 \Gamma^{\cdot} \mathrm{M}^{-3}\right)$, а найвищі $\left(>5,24 \Gamma^{\cdot} \mathrm{M}^{-3}\right)-$ із жовтня по травень. Розроблена номограма для визначення зміни кон- центрації кисню, розчиненого у воді внаслідок роботи пульверизаційного аератора в умовах розташування метеостанції Рава-Руська, дає змогу планувати дії під час рекультивації озер шляхом насичення бідних киснем шарів води. 3 огляду на значення коефіцієнта детермінації $\mathrm{R}^{2}=0,9149$ рекомендовано обережність під час моделювання ефектів штучної аерації вод із низьким вмістом кисню.

\section{Перелік використаних джерел}

Aerator, (2019). Technologia rekultywacji jezior głębokich. Technologia rekultywacji jezior płytkich. Technologia mobilnej aeracji pulweryzacyjnej z precyzyjną inaktywacją fosforu. Retrieved from: www.aerator.pl

Arkhiv pohody, (2007-2017). Rozklad pohody v Ukraini, TOV "Rozklad Pohody", 2004-2019. Retrieved from: http://rp5.ua/Pohoda_v_Ukraini. [In Ukrainian].

Bashutska, U. B. (2019). Pytannia rekultyvatsii ozer iz zastosuvanniam pulveryzatsiinoho aeratora vody. Suchasnyi stan i perspektyvy rozvytku landshaftnoi arkhitektury, sadovo-parkovoho hospodarstva, urboekolohii ta fitomelioratsii: Materialy mizhnarodnoi naukovo-praktychnoi konferentsii, Lviv, April 4-5, 2019. (pp. 210212). Lviv: NLTU Ukrainy. [In Ukrainian].

Chańko, A., Krysztofiak, A., Podsiadłowski, S., Prawniczak, S., Stachowiak, A., \& Trafis, M. (2001). Urządzenie do oczyszczania i napowietrzania akwenów wodnych. Opis patentowy PL 182023 B1, 4 p.

Konieczny, R. (2002). Wpływ energii jednostkowej aeracji pulweryzacyjnej na nasycenie tlenem wód otwartych. Akademia Rolnicza w Szczecinie, Wydziat Ksztaltowania Srodowiska i Rololnictwa, praca doktorska, maszynopis, $139 \mathrm{p}$.

Konieczny, R. (2013a). Wyznaczenie strat objętości strumienia wód aeratora pulweryzacyjnego. Problemy intensyfikacji produkcji zwierzęcej z uwzględnieniem infrastruktury, ochrony środowiska i produkcji energii alternatywnej. Opracowanie monograficzne. Instytut Technologiczno-Przyrodniczy $w$ Falentach, Oddziat Warszawa. Wyd. Instytut Technologiczno -Przyrodniczy Falenty, (pp. 132-137). Konieczny, R. (2013b). Wpływ wybranych parametrów technicznych i technologicznych na wydajność aeratora pulweryzacyjnego. Monografie $n r$ 15. Inżynieria $w$ rolnictwie. Falenty: Wyd. Instytut Technologiczno-Przyrodniczy, $145 \mathrm{p}$.

Osuch, E. (2014). Dyfuzja gazów podczas aeracji pulweryzacyjnejnaddennej warstwy wody jeziornej. Uniwersytet Przyrodniczy $w$ Poznaniu, Wydziat Rolnictwa i Bioinżynierii, Instytut Inżynierii Biosystemów, praca doktorska, maszynopis, $135 \mathrm{p}$.

Osuch, E., \& Podsiadłowski, S. (2012). Efficiency of pulverizing aeration on Lake Panieńskie. Limnological Review, 12(3), 139-146.

Osuch, E., Osuch, A., Podsiadłowski, S., Przybył, J., \& Walkowiak, R. (2015). Zmienność emisji gazów podczas aeracji pulweryzacyjnej, [w:] Aktualne problemy inżynierii biosystemów. Uniwersytet Przyrodniczy w Poznaniu, Poznań, (pp. 44-52).

Podsiadłowski, S., Osuch, E., Przybył, J., Osuch, A., \& Buchwald, T. (2018). Pulverizing aerator in the process of lakerestotation. Ecological Engineering, 121, 99-103. https://doi.org/10.1016/j.ecoleng.2017.06.032

Resursy. (2019). Vodni resursy Ukrainy. Retrieved from: http://www.nbuv.gov.ua/node/3972. [In Ukrainian].

\section{U. B. Bashutska}

Ukrainian National Forestry University, Lviv, Ukraine

\section{LAKE RECLAMATION BY THE METHOD OF PULVERISING AERATION OF WATER IN THE CONDITIONS OF LOCATION OF METEOROLOGICAL STATIONS OF RAVA-RUSKA}

The main threat to lakes in Ukrainian climate condition is factors increasing the rate of eutrophication, which results in phytoplankton growth and the general deterioration of water quality. The balance between complex of organic compounds and the oxygen in the water is disturbed. Natural oxygenation of deep water layers needs a lot of time, because it relies on the diffusion of oxygen 
from the epilimnion layer. The intensity of the diffusion processes is largely insufficient, especially in summer. The technology of reclamation of lake by technical method in the conditions of location of the meteorological station in Rava-Ruska is considered in the article. The experience and results of the work of Polish scientists are analyzed. Some positive results were noted when applying in the reclamation of natural and artificial reservoirs by pulverising water aerator that sprays water in the air. The distribution of pulverising water aerators used for lake reclamation is presented. A wind driven pulverising water aerator by Podsiadlovsky's concept was described. This technology involves the use of wind energy for oxygen saturation in the lower lake area. The work of the aerator provides formation on the cumulative depth of living space. In this space, phytoplankton, zooplankton and fish that feed there are intensively developing. Regular fish catches can reduce the lake trophy and systematically improve the quality of the water. Pulverization aerator of water with wind driven air in the conditions of the location of the weather station in Rava-Ruska can provide dissolution of oxygen in the bottom waters ranging from 4.86 to $5.53 \mathrm{~g} \cdot \mathrm{m}^{-3}$. The lowest concentrations of dissolved oxygen in water occur in July and August $\left(4.86 \mathrm{~g} \cdot \mathrm{m}^{-3}\right)$, while the highest $\left(>5.24 \mathrm{~g} \cdot \mathrm{m}^{-3}\right)$ is from October to May. A nomogram has been worked out and described to determine the oxygen content dissolved in water during the month, as a result of the operation of a pulverising water aerator with the location of Rava-Ruska meteorological station conditions. It is recommended to use a pulverizing water aerator with a wind drive for the reclamation of lakes in Ukraine.

Keywords: reclamation of lakes; pulverising water aerator; wind energy; dissolved oxygen. 